
品川区立萑原第一中学校○宮 本 政 明 東京女子体育大学高島稔 東 京 教 育 大学 并上三佐男 東京教育大学附属中学枚

$$
\text { 八代美代子，佐藤 良男 }
$$

1. 研究の目的 前年度の継続として，評価活動を中 心考えて基碗条件を整備した場合，学習者の活動が゙ のように進展するのかを研究したい，今回は特に評価計 画の与方方評価活動とに大きなポイントがある。つま り学習評価を中心とした計画を与克ることにより，学習 活動にどのような変化があるかをみていく．

2. 単漗竍面表 今年度は計画を持たせる場合にる， できるだけ一元化したものの中で整理し，しかも生徒の 活動が活発になるように考えくふらした。

\section{3. 学翼神画表よ呯価活助について}

陸上競技（障害走）の例

(1) 目標の持ち方・持たせ方

段階表の利用，記録のとり方を明示することによつて 個人のねらい，特に拔術のねらいがはつきりしてきた。 しかも計画表，段階表を利用し，挍術的段陵に相応した ねらいを持ちやすかつた。

(2) 学習活動の変化
段倩表確認後、練習にとりくみ，学習過程を生かした 活動が目立つてきた．また記録をとる関係上，直しあう 活動や上級目さして過程のとり方がかなり好転した。

(3) 記録のとり方

ややつけ方に複雑なところがあつたが，細部まで記録 したので次の時間の課題を持つのに役立つている. しか し記入すれがないようにとか，段階の解訳について統一 したらつしが必要となる.

\section{4. まとめ}

計画表については前年度と比へ整理され，綀習のはじ めやあい間に利用しやすく，ねらい，内容，過程などに ついての関保がつかみすく活動を活発にするのに役立 つている.

段階表や記録表を使らことによつて

。個人やグループの課題をつかみやすい

。拉術の程度が明確になり評価活動の正確化に役立 ち，学習過程の確かめとなる

\section{5. 今後の㗚焉}

(1) 種目対象を広げて実証したい。

（）種目による特性を更に明らかにしたい。

(3) マナー，健康安全と技術との結びつき

(4) 個人とグループのねらいと記録について

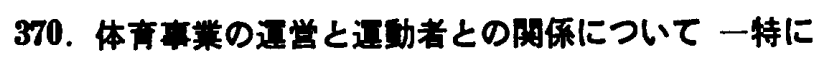

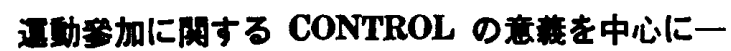
東京教育大学 $\mathrm{O}$ 于 土 正 CONTROL の概念は，各分野に和ける管理の機能あ るいは要素または過程の問題として最る古くから論議さ れてきた。しかし，体育の問題としては，必らずしも具 体的に明らかにされているとは言えない。特に他の分野 で言われる CONTROL とのちがいもあり得るにちが いない点に注意して，体育管理に信るるれる陚みるこ とにした。

R.C. Davis $の$ administrative control と operative control の区別は，CONTROL を構造的にとらえるる のとして注意を引かれるものがある.この発想にもとづ いて考えると、けつきよく，体青の場合の特殊性は，体 育事業と運動者との関倸をめぐる CONTROL にある と思われる。

CLUB Service についてみると、いわゆる自発的な クラフ活動の場合と，特に学校教育でみられるところの 「強制されたクラブ活動」のちがいがある.その後者の 場合, 運動者の参加を促がす働らきは、ちようど operative conntrol の中の一つとみられる direction の概念
を当てることができうりこれが PROGRAM Service の場合になる，CONTROL との働らきは，さら に複雑になる.すなわち，同しく運動者に向けられる CONTROL といっても，個人に向けられたすのと Class K向けられたすのの区别を重視する必要があるか らである，体育管理に批る CONTROL の特殊性は， それ以外には認められないとすると，つぎの問題は， CONTROL のそのような働らさがどのような意義（体 育事業の運営上）をむたらすものか，といらことになろ 5 .

例えば，参加を CONTROL されたクラブ活動者 (Required C.) は，真の意味の C 運動者というより は，実質的には， P 運動者と同質のものとなる頃向が 察しられる.これまでの調查例でみると， $\mathrm{P}$ 運動者の 中であ特に「競技的 $\mathrm{P}$ 運動者」と著るしく近似してい ることが確認された．とすると，それは，スボーツ教室 に変質していることを示さしていよう．これらの傾向を どう解するかは，運営の目的のおきどころによるが，い ずれにしても，变質傾向を認識して運営に当たることの 重要性は，强調されねばならないであろう。 